\title{
Modern Wide-span Spatial Metal Structures in Russia
}

\author{
Pavel Yeremeyev G* \\ The Central Research Institute of Civil Engineering (TsNIISK) 109428, Moscow, Russia, 2-nd Institutskaya str., 6, Russia
}

Submission: November 12, 2020; Published: November 18, 2020

*Corresponding author: Pavel Yeremeyev G, The Central Research Institute of Civil Engineering (TsNIISK) 109428, Moscow, Russia, 2-nd Institutskaya str., 6, Russia

\begin{abstract}
A great number of unique wide-span structures have been built in Russia in recent years. More than 30 new stadiums and covered arenas have been or are being built for the 2014 Winter Olympics and the 2018 Football World Cup. The most interesting of these are briefly described below. The objects were designed, manufactured and erected with the participation of TsNIISK.

Keywords: Wide-span construction; Spatial metal structures
\end{abstract}

\section{Opinion}

Lokomotiv Football Stadium (Figure 1) with a capacity of 30,000 . Its roof (206 by $157 \mathrm{~m}$ ) covering the stands has an oval shape in plan and is suspended on guys attached to four reinforced-concrete pylons with a height of about $50 \mathrm{~m}$ erected at the stadium corners and supported by guy-wires.

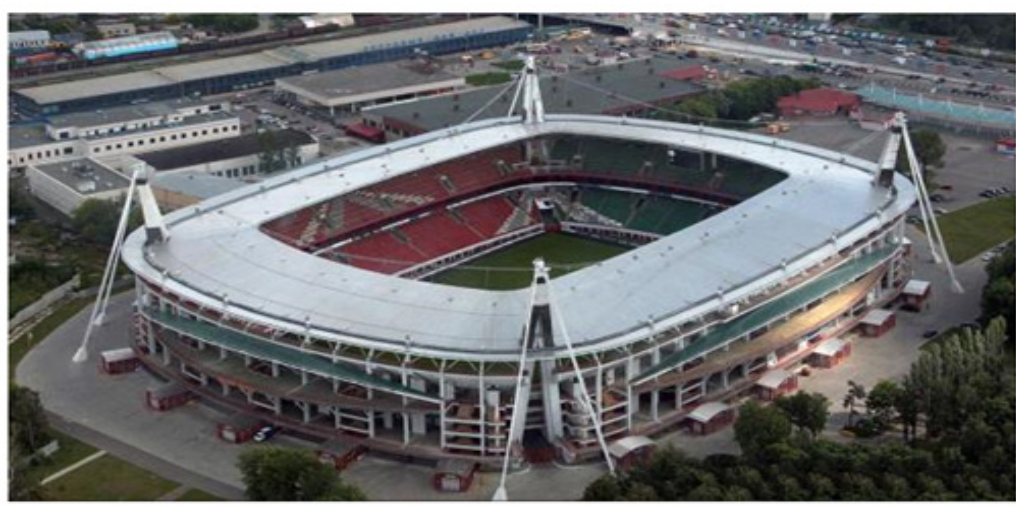

Figure 1: Lokomotiv Football Stadium.

Olympic Stadium Fisht (Figure 2) with a capacity of 50,000 has an oval shape in plan ( 285 by $240 \mathrm{~m}$ ). The main elements of the roofs are two main lattice arches with a span of $285 \mathrm{~m}$ and a height of $70 \mathrm{~m}$. Secondary semi-arches with spans from 18.0 to $71.0 \mathrm{~m}$ are erected in perpendicular direction.

Luzhniki Stadium (Figure 3). It was proposed to tear down the arena and build it anew in order to comply with FIFA requirements. However, it was decided later to upgrade the arena. The stadium now has a roof with a longer projection, and new stands for 81,000 spectators are being built.

Kazan Arena (Figure 4) with a capacity of 45,000 is a circle (diameter of $250 \mathrm{~m}$ ). Bearing metal structures consist of footing and cantilever trusses. The footing is a spatial closed three-chord truss which is supported through hinge joints by eight reinforced-concrete pylons at the stadium corners. 


\section{Civil Engineering Research Journal}

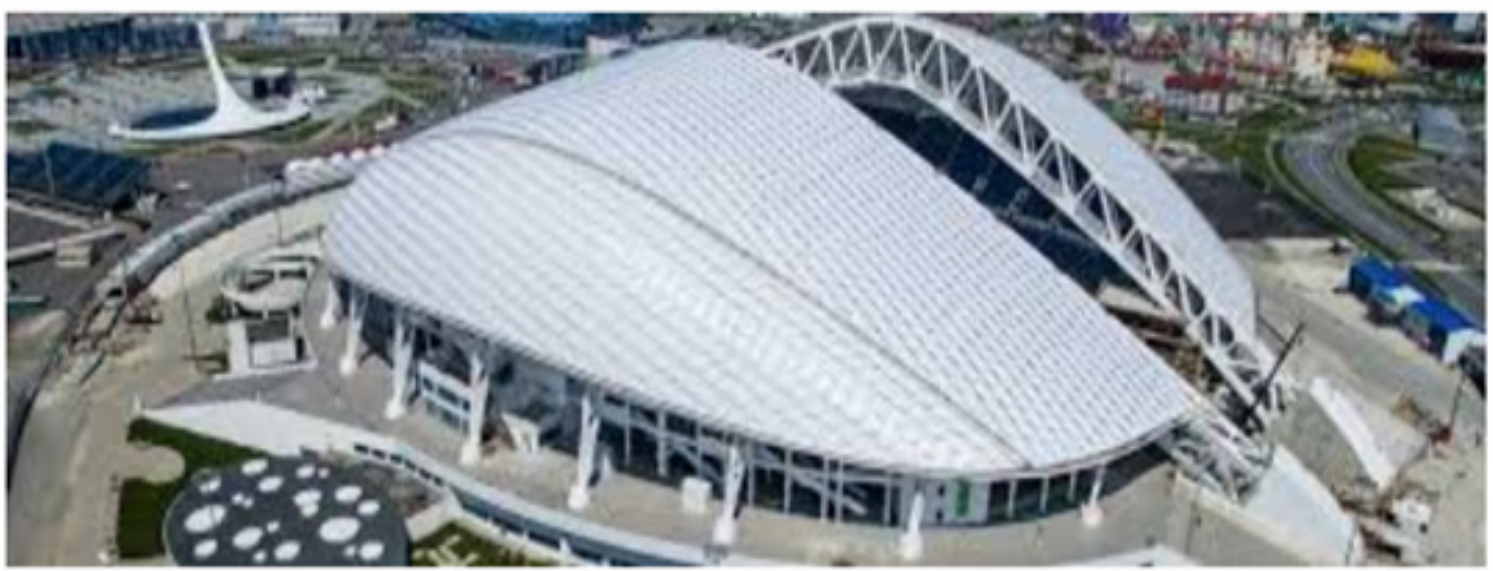

Figure 2: Olympic Stadium Fisht.

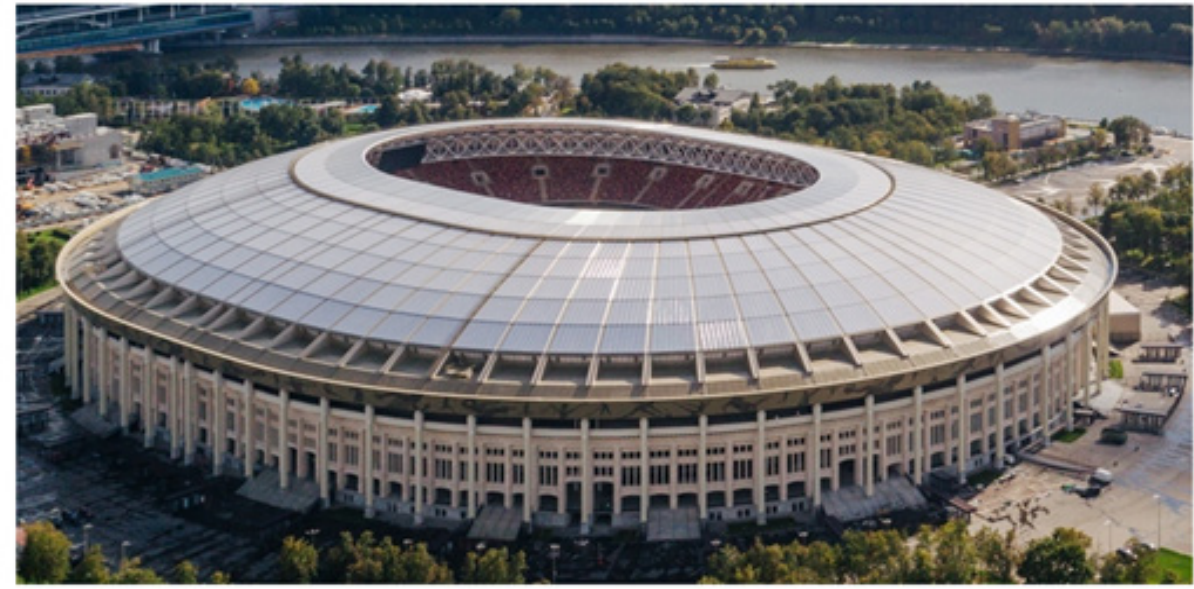

Figure 3: Luzhniki Stadium.

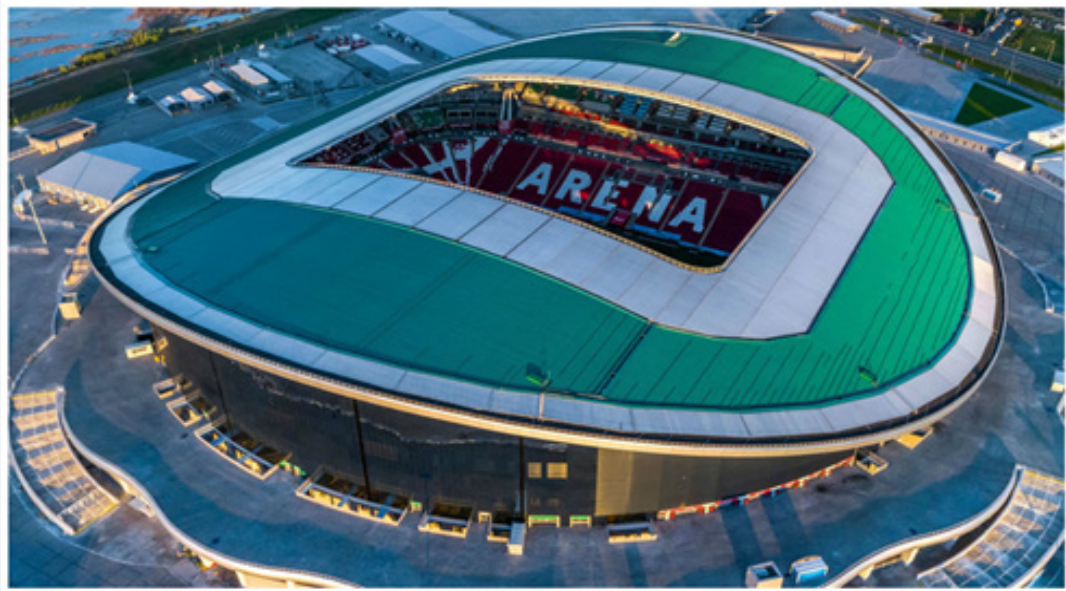

Figure 4: Kazan Arena. 


\section{Civil Engineering Research Journal}

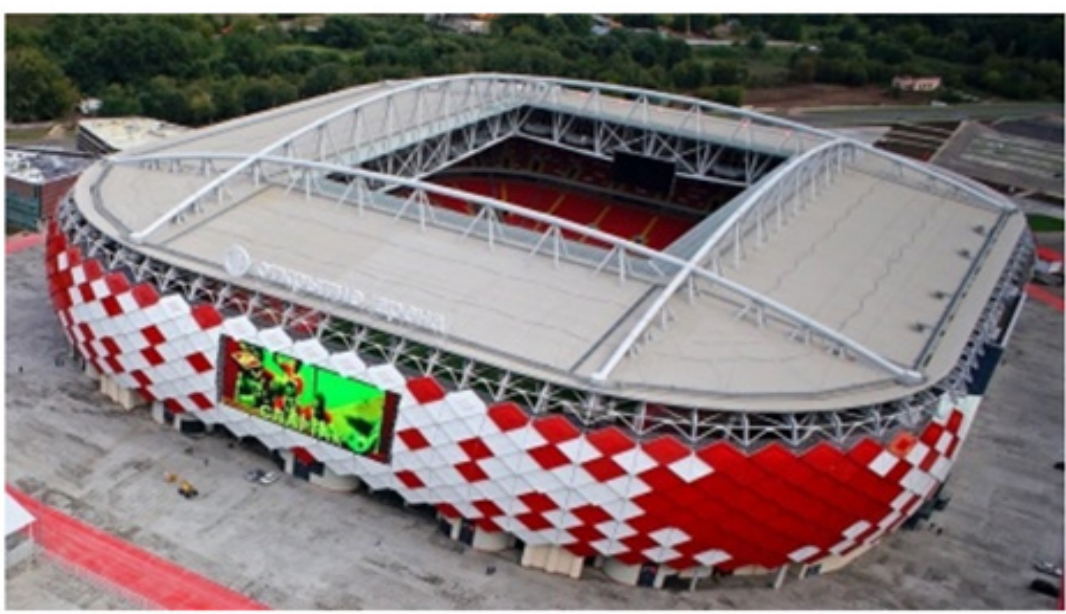

Figure 5: Otkritie Arena

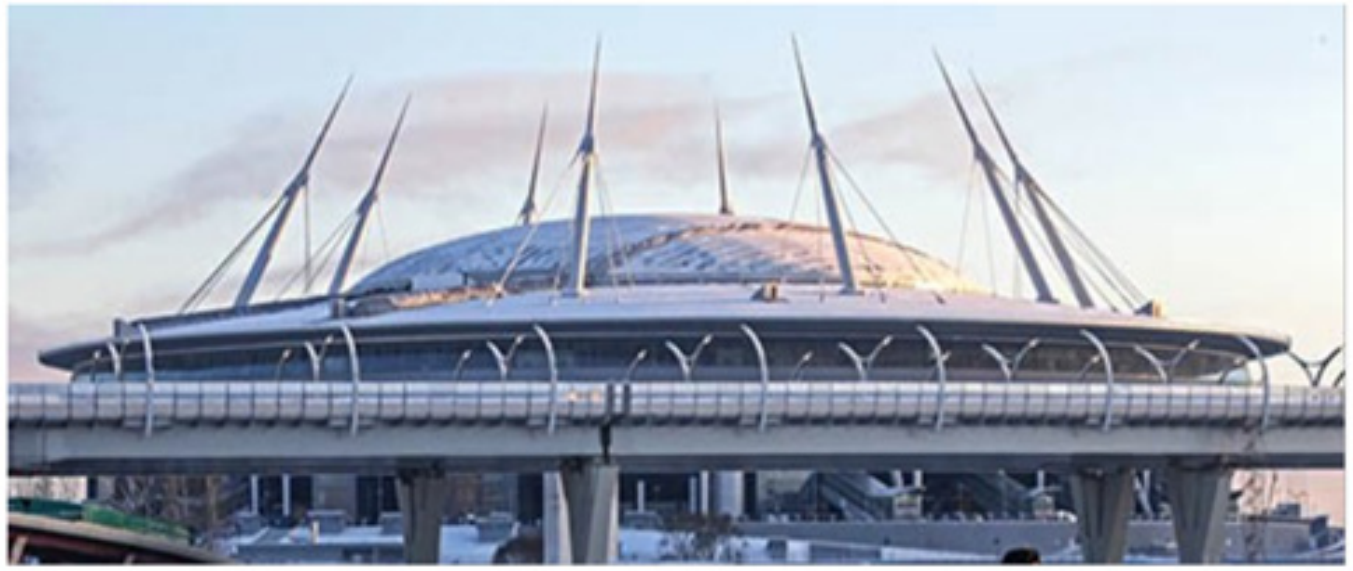

Figure 6: Saint Petersburg Stadium.

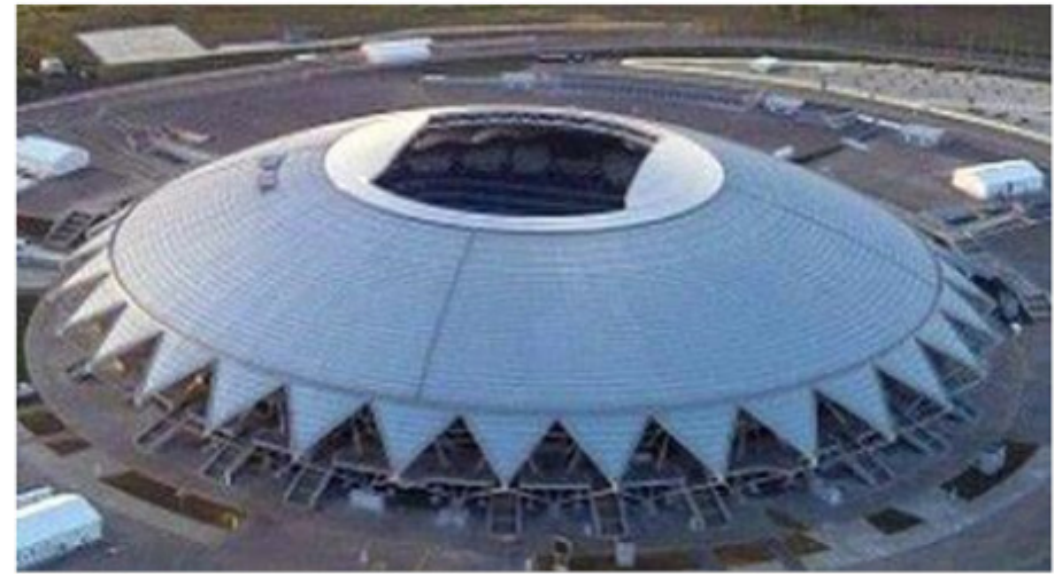

Figure 7: Samara Arena. 


\section{Civil Engineering Research Journal}

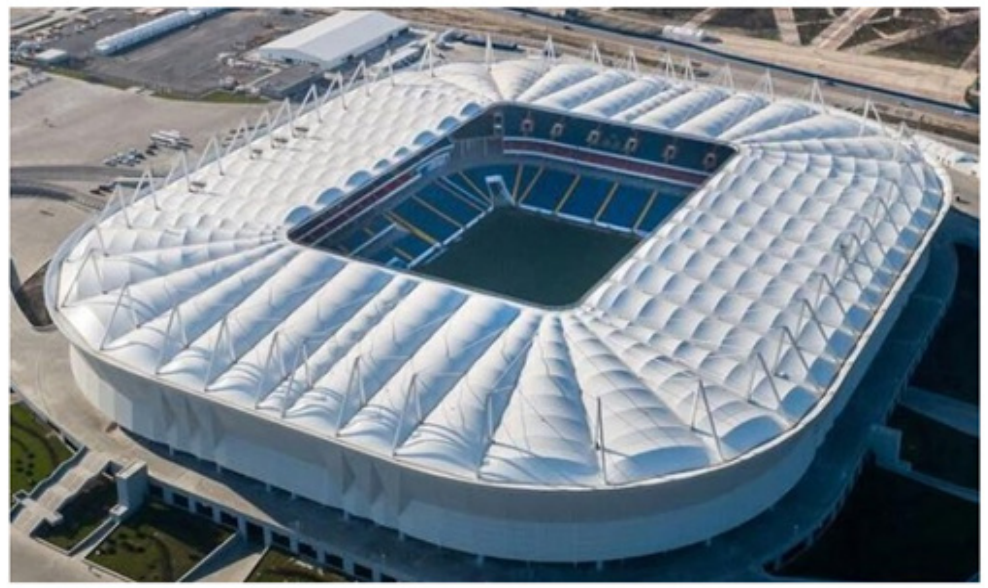

Figure 8: Rostov Arena.

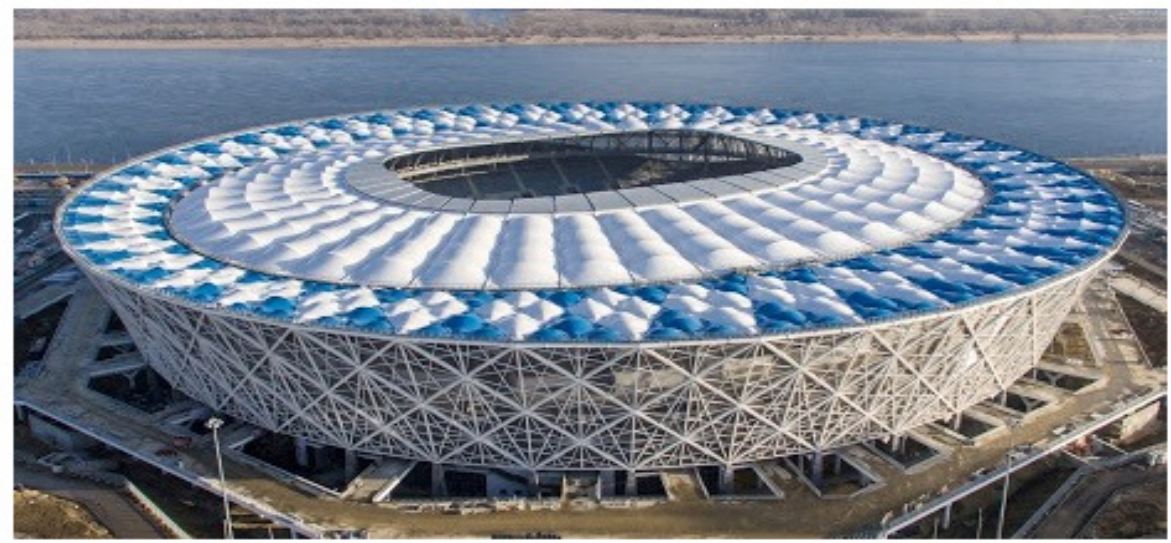

Figure 9: Volgograd Arena.

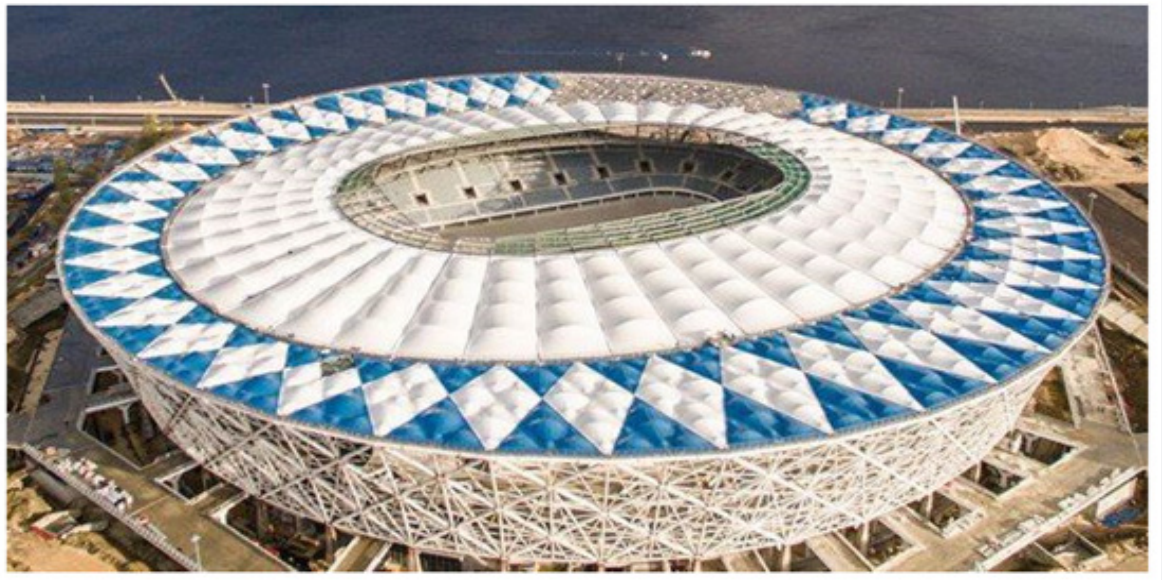

Figure 10: Nizhniy Novgorod Stadium. 


\section{Civil Engineering Research Journal}

Otkritie Arena (Figure 5) with a capacity of 42,000. The stadium in plan is a rectangle with rounded corners $(220$ by $179 \mathrm{~m}$; height is $51 \mathrm{~m}$ ). Metal structures include four main trusses around the field. Longer trusses with a span of $217 \mathrm{~m}$ and shorter trusses with a span of $180 \mathrm{~m}$. The trusses are supported in eight points by reinforced-concrete pylons at the stadium corners.

Saint Petersburg Stadium (Figure 6) with a capacity of 62.000 has a transformable central part and a movable field. The stadium in plan is a circle (diameter of $296 \mathrm{~m}$ ). Its height is 56.6 $\mathrm{m}$. The metal structures of the fixed roof consist of a framework shaped like a biconvex lens with a central aperture over the football field. The structure includes radial and circular trusses and links. The roof is suspended on bearing cables to eight slanted steel pylons with a height of $100 \mathrm{~m}$.

Samara Arena (Figure 7) with a capacity of 45,000 is a round dome (diameter of $300 \mathrm{~m}$, height $60 \mathrm{~m}$ ). Its main supporting elements are 32 radial cantilever three-chord lattice trusses made of round steel pipe. The radial trusses with a projection of 91.2 $\mathrm{m}$ have variable height and a maximum width of $10.2 \mathrm{~m}$ at their supported ends. The radial elements are combined into a spatial system by circular trusses.

Rostov Arena (Figure 8) with a capacity of 45,000 has an oval shape in plan ( 257 by $219 \mathrm{~m}$ ). Its main bearing structure is a system of 46 radial cantilever beams joined by circular girders and links. The flat cantilever beams with a projection of $51 \mathrm{~m}$ are attached by slanting cables to the tops of pylons placed on the stadium perimeter. The joints between the cables and pylons are connected by guy-wires to reinforced-concrete pile caps.

Volgograd Arena (Figure 9) with a capacity of 45,000 an oval shape in plan ( 240 by $202 \mathrm{~m}$ ) and a height of the roof $49.5 \mathrm{~m}$. The roof is a system of the "bicycle wheel" type with one compressed outer ring and two elongated inner rings linked by a system of 44 radial cable trusses.

Nizhniy Novgorod Stadium (Figure 10) with a capacity of 45,000 . The roof over its stands is designed as a shell with radial and circular elements; its main bearing elements are 44 radial lattice cantilevers joined by circular trusses and links.

Mordovia Arena (Figure 11) with a capacity of 45,000. The stadium is a domed structure with an oval base. Its dimensions along the main axes of symmetry are 228 by $210 \mathrm{~m}$. The main bearing elements of the roof are 88 cantilever curved-chord lattice trusses with a projection of $49 \mathrm{~m}$. Main bearing structures are made of steel pipes connected without gusset plates.

Yekaterinburg Arena (Figure 12) with a capacity of 35,000. The structure has a round shape in plan with a diameter of about $180 \mathrm{~m}$. Its roof is a sagging shell made of a system of radial and circular rigid steel strings with a central aperture. The structure features a 100-m opening in external walls.

Kaliningrad Arena (Figure 13) with a capacity of 35,000. The structure in plan has the shape of a rectangle with rounded corners $(167 \times 204 \mathrm{~m})$. It main bearing structure is a space frame with radial and circular trusses connected by links. Planar radial trusses with a projection of $38 \mathrm{~m}$ are suspended from the tops of pylons located on the stadium perimeter. The joints between the suspension cables and pylons are connected by guy-wires to the framework of the stands.

Krasnodar Arena (Figure 14) with a capacity of 35,000. The structure has an oval plan (190 by $230 \mathrm{~m})$. The roof is a stayed system of the "bicycle wheel" type with two compressed outer rings and one elongated inner ring linked by a system of 56 radial cables.

CSKA Stadium with a capacity of 36,000 has a rectangular shape in plan ( 215 by $179 \mathrm{~m}$ ). The roof over the stands is hyperbolic paraboloid in shape (Figure 15). Overall width of the roof is $48 \mathrm{~m}$, with cantilever projections of $40 \mathrm{~m}$. Its bearing structures are cantilever trusses with guy-wires.

VTB Arena (Figure 16) with 33,000 seats has an oval shape in plan ( 300 by $187 \mathrm{~m}$ ) and a height of $66 \mathrm{~m}$. Its roof also covers an indoor arena with 13,000 seats.

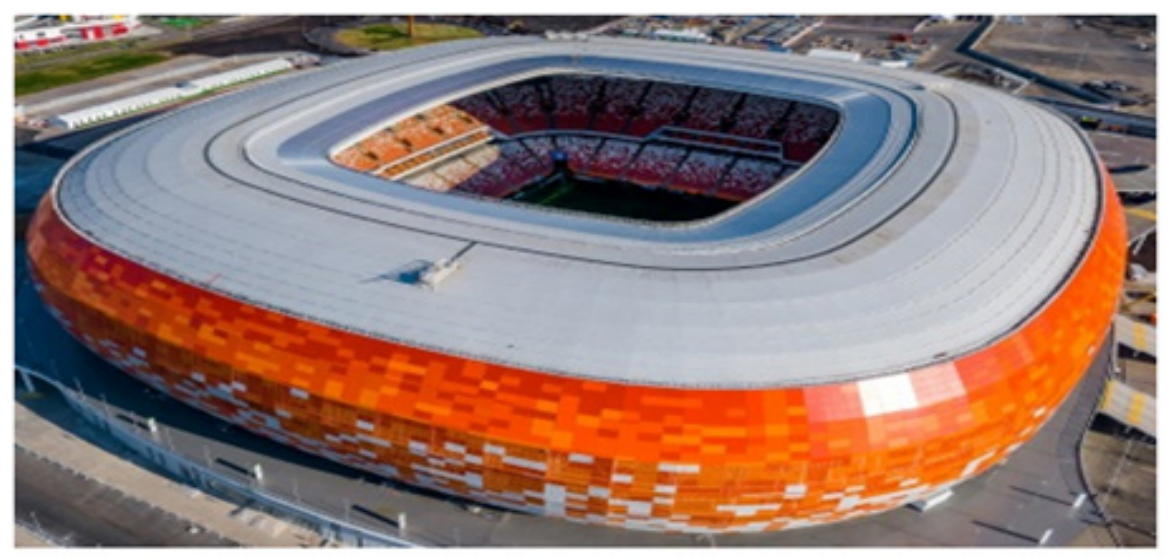

Figure 11: Mordovia Arena. 


\section{Civil Engineering Research Journal}

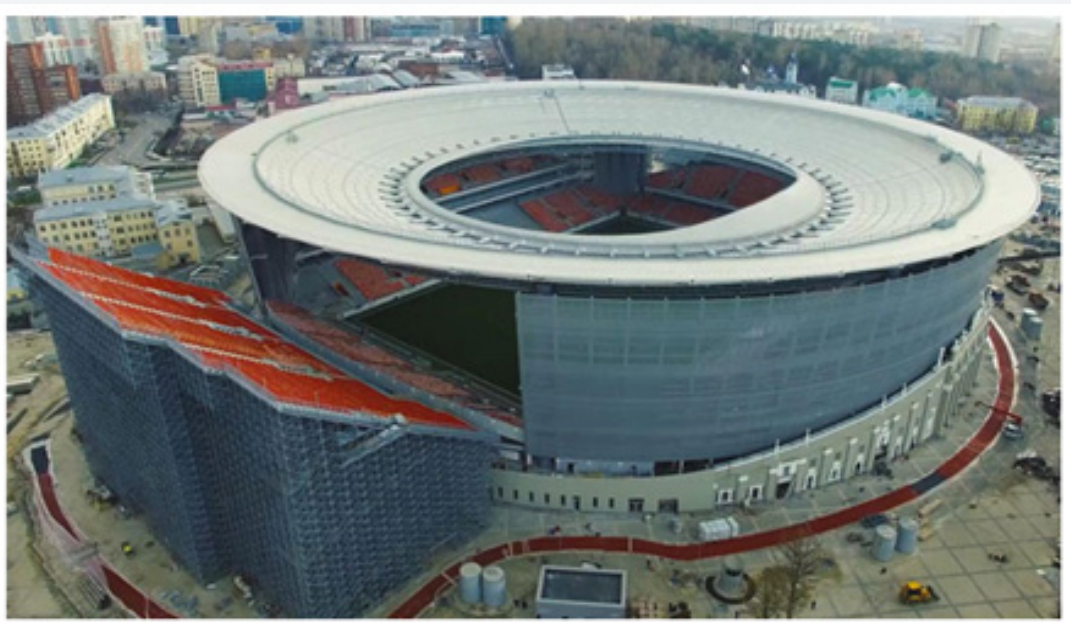

Figure 12: Yekaterinburg Arena.

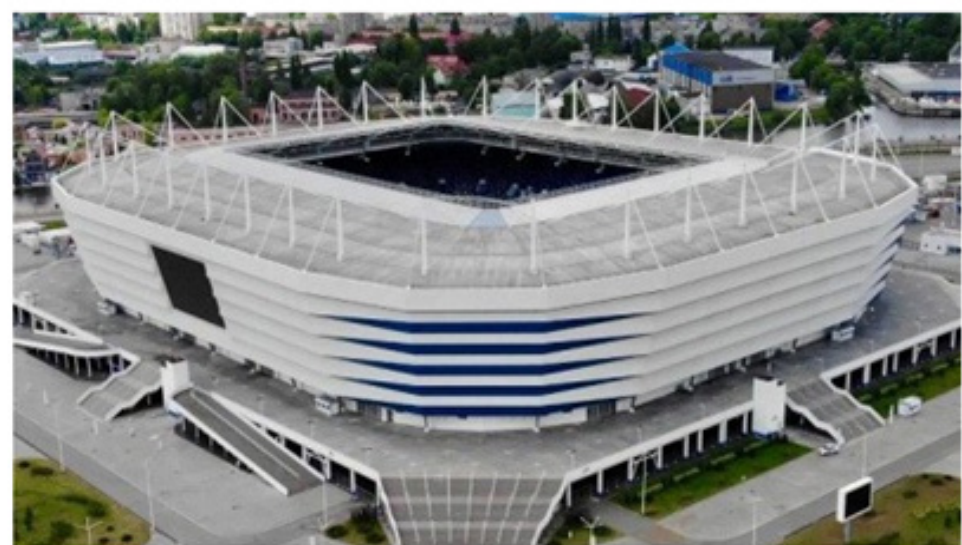

Figure 13: Kaliningrad Arena.

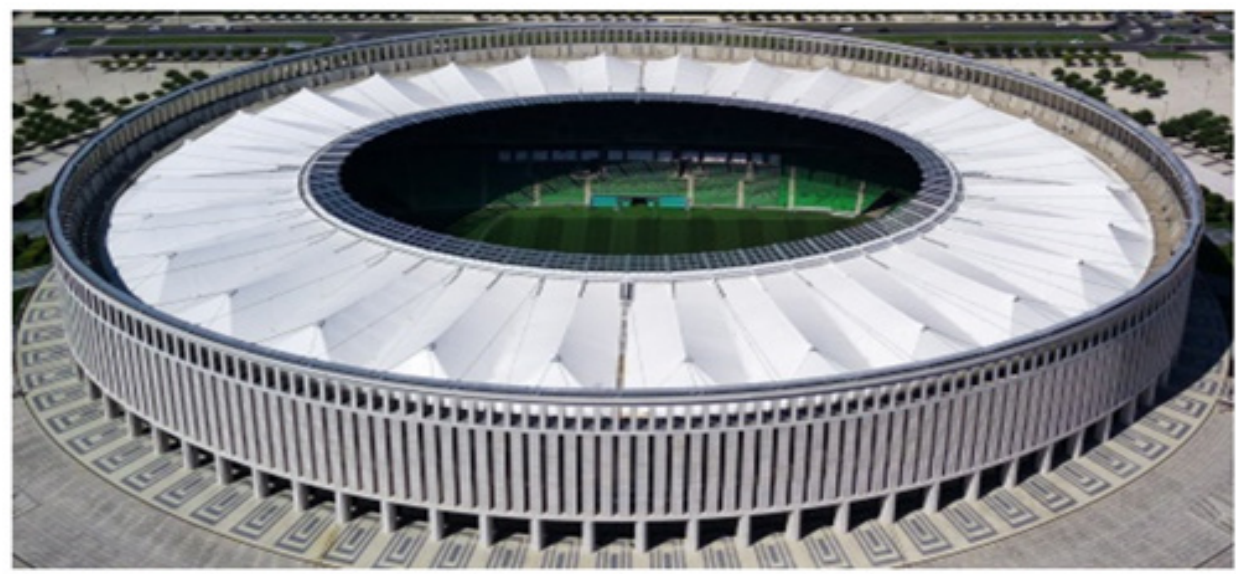

Figure 14: Krasnodar Arena. 


\section{Civil Engineering Research Journal}

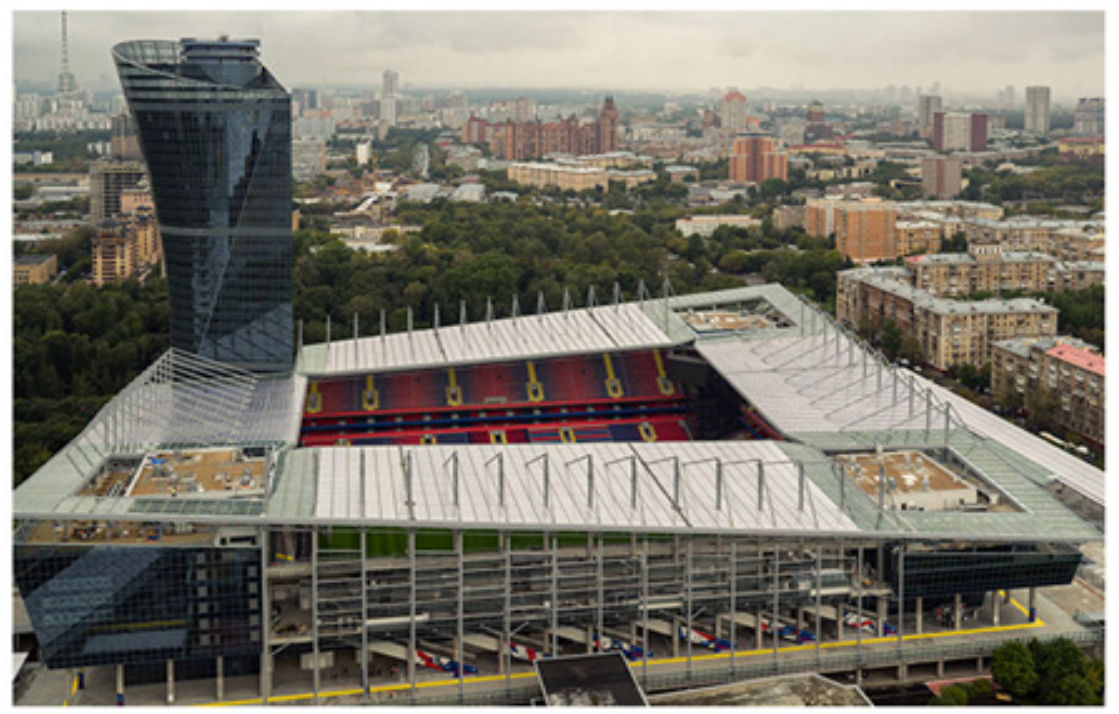

Figure 15: CSKA Stadium.

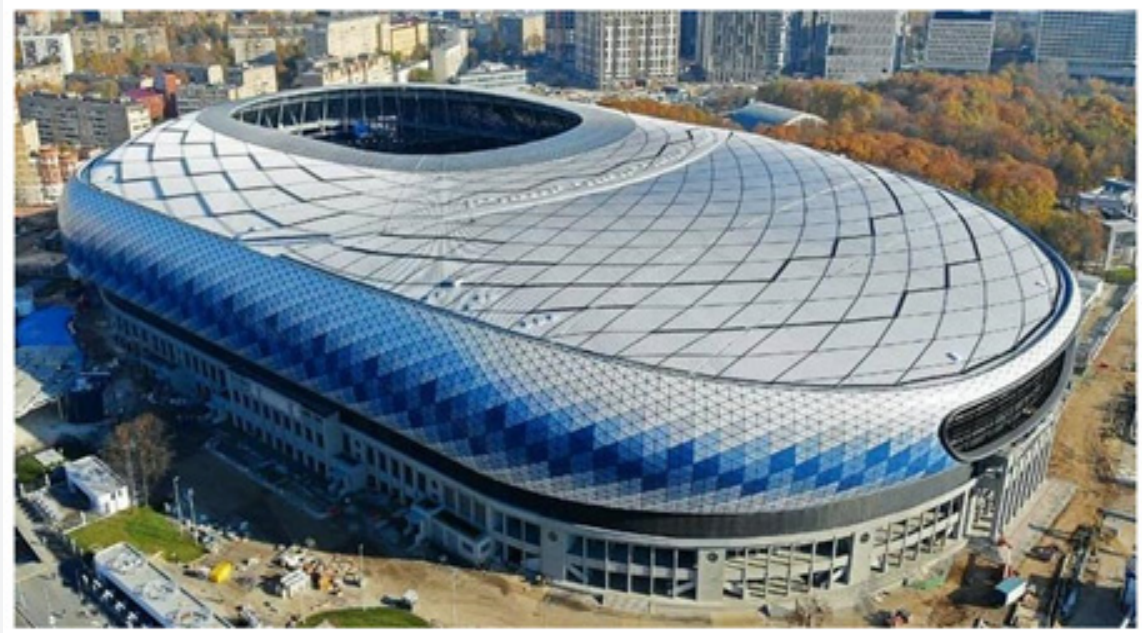

Figure 16: VTB Arena.

(C) This work is licensed under Creative
Commons Attribution 4.0 License

Your next submission with Juniper Publishers will reach you the below assets

- Quality Editorial service

- Swift Peer Review

- Reprints availability

- E-prints Service

- Manuscript Podcast for convenient understanding

- Global attainment for your research

- Manuscript accessibility in different formats

( Pdf, E-pub, Full Text, Audio)

- Unceasing customer service

Track the below URL for one-step submission https://juniperpublishers.com/online-submission.php 